
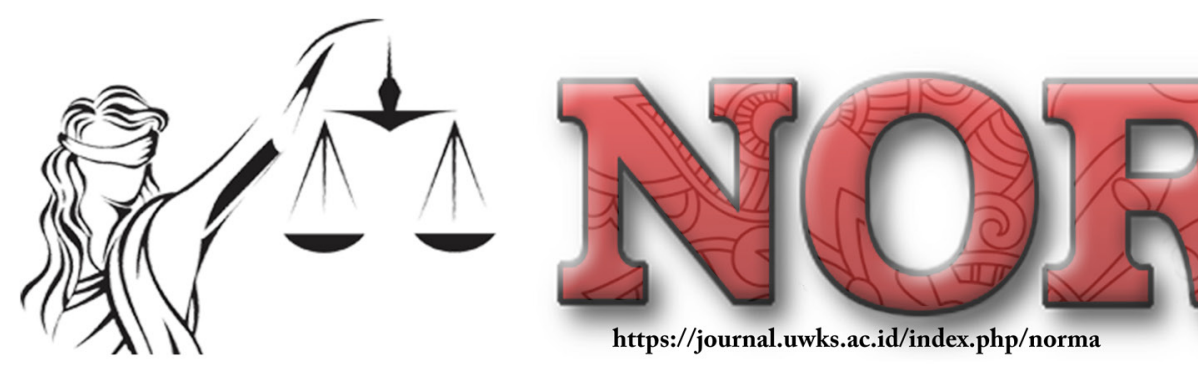

\title{
The Ambiguity of Resi Gudang (Warehouse Receipt) Guarantee Institution Legal Standing
}

\author{
Safira Oktavia Putri \\ Law Faculty, Universitas Airlangga \\ e-Mail: safiraop16@gmail.com
}

\begin{abstract}
:
Farmers usually use warehouse receipts to obtain debt with commodity objects stored in the warehouse as a debt security. Warehouse receipts as valuable objects, of course, have the potential to be tied up in a debt bond that serves as a security for these debts. For objects to be used as collateral in a credit agreement, they must meet certain conditions, namely, economic value and transferability. Therefore, it is necessary to conduct a study of warehouse receipts to be used as collateral objects, given the characteristics of warehouse receipts as valuable objects and the property rights attached to the warehouse receipts. This research is normative research with a statutory approach. The result of this research is that warehouse receipts can be used as collateral objects but with some adjustments. And based on the existing regulations, it is understood that the warehouse receipt arrangement does not create a warehouse receipt guarantee institution.
\end{abstract}

Keywords: Warehouse Receipt; Debt; Collateral.

\author{
Article's History: \\ Received: \\ February 16, 2021; \\ Peer-Reviewed: \\ February 24, 2021; \\ Accepted: \\ February 27, 2021; \\ Published: \\ March 5, 2021. \\ DOI:
}

10.30742/nlj.v18i1.1292

\section{INTRODUCTION}

The times and the era of globalization will continue to advance along with human growth. Humans themselves are zoon politicon and homo economicus, which means that humans will not be able to live alone without the help of interaction with other people. The interaction model always pays attention to profits and losses. The calculation of gains and losses is not still related to matter but not associated with the matter, such as ego. Human activities that calculate profit and loss related to the material are known as business, while business must always have a legal umbrella. ${ }^{1}$

The high level of community needs at this time sometimes causes people to have urgent needs. In urban and rural communities, sometimes, their income is not necessarily sufficient to meet the community's needs. Apart from working, sometimes people choose to invest, sell some of their assets, or pledge their assets temporarily until they go into debt. Accounts receivable is an easy and strategic shortcut. ${ }^{2}$

\footnotetext{
${ }^{1}$ Gatot Supramono, Perjanjian Utang Piutang (Jakarta: Kencana Media, 2013) 1.

2 Suwandi Suwandi, "Kedudukan Jaminan Antara Utang-Piutang Dan Rahn" Jurisdictie: Jurnal Hukum dan Syariah. 7.2 (2016): 103.
} 
Accounts receivable connotes money and objects borrowed to pay back what has been received with the same. ${ }^{3}$ With this debt system, the public can get a loan where the conditions are with a guarantee. The importance of collateral as protection for creditors so that debtors pay off debts from the guaranteed object. If in the relationship between the debtor does not fulfill the achievement voluntarily, the creditor has the right to demand fulfillment of his debt when the debt is collectible, namely against the debtor's assets which are used as collateral. ${ }^{4}$

In the process of debt and credit, what can be guaranteed is not the origin of all objects because it is not certain that every item is always a valuable object and does not necessarily have an economic value. What can be guaranteed is every object which is a valuable object owned by anyone who wants to be in debt because valuable items are considered to have economic value. Examples of valuable items such as houses, gold, vehicles, land certificates, or securities are warehouse receipts.

Warehouse receipts are securities in documents as proof of ownership of a commodity item stored in a warehouse. Currently, many people use warehouse receipts to be used as collateral to obtain financing. Financing is one of the problems that business actors often face, especially farmers and small and medium enterprises. ${ }^{5}$ So usually, people who have businesses such as in the field of commodities, especially farmers, use warehouse receipts as securities they own to be guaranteed, in contrast to urban communities who may secure their property in the form of gold or vehicles. When the harvest is high, the farmers experience difficulties due to the sharp decline in their crops' market price, and there is no place to store their produce. So it requires a place that can be used to keep the crops, so they don't get damaged. Another problem faced by farmers in Indonesia with the abundance of agricultural commodity crops is that poor warehousing conditions are an obstacle for farmers in saving their crops. To maintain the state of the harvest is still good while waiting for the desired price. With the warehouse system, the farmer's commodity goods can be stored in the warehouse, where the farmers will get a warehouse receipt as proof of ownership. So this warehouse receipt is usually used by farmers to obtain financing with a guarantee of commodity objects stored in the warehouse. ${ }^{6}$

Warehouse receipts as valuable objects, of course, have the potential to be tied up in a debt bond that serves as a security for these debts, which are known as collateral objects. However, for an item of guarantee, the legal aspects are quite diverse. For things

\footnotetext{
${ }^{3}$ Yuswalina, "Hutang-Piutang dalam Prespektif Fiqh Muamalah di Desa Ujung Tanjung Kecamatan Banyuasin III Kabupaten Banyuasin" Intizar. 19.2 (2016): 396.

${ }^{4}$ Fani Martiawan Kumara Putra, "Konstruksi Lembaga Jaminan Untuk Saham Sebagai Bentuk Dukungan Perkembangan Bisnis" Perspektif. 23.2 (2018): 67.

${ }^{5}$ Pusat Kebijakan Perdagangan Dalam Negeri, Analisis Efektifitas Sistem Resi Gudang Melalui Pasar Lelang Forward Komoditi (Jakarta: Kementerian Perdagangan Republik Indonesia, 2015) 1.

${ }^{6}$ Fitria Olivia, "Tanggung Jawab Pengelola Gudang Mengenai Resi Gudang Terhadap Kelalaian yang Mengakibatkan Kerugian" Jurnal Lex Jurnalica. 10.3 (2013): 162.
} 
to be secured as collateral in a credit agreement, they must meet certain conditions, namely, economic value and transferability. This is to make it easier in the execution process later. ${ }^{7}$

Warehouse receipts are objects with economic value, but some aspects can hinder the transfer of ownership rights to the warehouse receipts. Warehouse receipts are objects that can be used as objects of collateral. Therefore, it is necessary to conduct a study of warehouse receipts to be used as collateral objects, given the characteristics of warehouse receipts as valuable objects and how the property rights' nature is attached to the warehouse receipts.

\section{RESEARCH METHOD}

This research is a normative research, which means that this research examines the legislation's side, not reading social symptoms due to existing legislation. This research's approach method is a statutory approach (statute approach) and conceptual approach. This approach is used because the discussion in this study will refer to the Law and the concept related to the issue.

\section{DISCUSSION}

One example of the development of types of business activities in Indonesia is in the world of agriculture. Business activities that farmers can carry today are not just selling their crops to meet their daily needs, such as renting out their agricultural land with a production sharing agreement and guaranteeing their harvested objects to get money. However, in carrying out these business activities to meet needs, sometimes it can cause problems. For example, a common problem with agribusiness in Indonesia is the fall in crops' selling price during the primary harvest season. ${ }^{8}$ This is because farmers usually tend to have a uniform planting schedule so that all rice plantations receive sufficient irrigation, minimize pest attacks, and pursue optimal planting seasons. When the harvest is simultaneous, rice farmers cannot store their harvest for longer because they have run out of costs and do not have adequate storage warehouses. Then it causes the selling price of the crop to fall. Therefore, if farmers sell their produce directly, they will often suffer losses. The government then solves the classic problem of falling agribusiness commodity prices during the primary harvest season with the Warehouse Receipt System. ${ }^{9}$

The definition of warehouse receipt according to Law no. 9 of 2011 regarding the Warehouse Receipt System (from now on referred to as the Warehouse Receipt

7 Gentur Cahyo Setiono, "Jaminan Kebendaan dalam Proses Perjanjian Kredit Perbankan (Tinjauan Yuridis Terhadap Jaminan Benda Bergerak Tidak Berwujud)" Transparansi Hukum. 1.1 (2018): 4, Available: http://ojs.unik-kediri.ac.id/index.php/transparansihukum/article/view/159.

${ }^{8}$ Iswi Hariyani and R Serfianto, Resi Gudang Sebagai Jaminan KreditEAlat Perdagangan (Jakarta: Sinar Grafika, 2010) 1.

${ }^{9}$ Ibid., 3. 
Law), Article 1 states, "Warehouse Receipt is a document of proof of ownership of goods stored in the warehouse issued by the Warehouse Manager." Meanwhile, the Warehouse Receipt System is an activity related to the issuance, transfer, and settlement of warehouse receipt transactions.

Warehouse receipts are essential, effective, and negotiable instruments and swapped in a country's trade financing system. Besides, warehouse receipts can also be used as collateral or received as proof of delivery of goods in the context of fulfilling a maturing derivative contract, as occurs in a futures contract. ${ }^{10}$

Based on the explanation of the Warehouse Receipt Act, warehouse receipts are a document of title for goods that can be used as collateral because warehouse receipts are guaranteed with certain commodities under the supervision of an accredited warehouse manager. In other words, a warehouse receipt is a receipt in the form of a letter issued by the warehouse owner, which is given as proof of ownership of the object deposited/placed in the warehouse to the owner of the item. Every owner of an entity who keeps an object in the warehouse is entitled to receive a warehouse receipt. Warehouse receipts will be issued after the owner submits the items. Lost or damaged warehouse receipts, warehouse managers are required to issue replacement warehouse receipts at the request of warehouse receipt holders. Replacement warehouse receipts have the same legal force as warehouse receipts that have been replaced.

The Warehouse Receipt System is the result of the further development of the Fiduciary Guarantee System, especially those specifically related to the object of collateral for movable objects in the form of stocks of agricultural products, plantations, non-bank financial institutions, as well as from investors who are interested in buying warehouse receipt derivative products through the stock exchange.

Warehouse receipts as a system, relying on the warehouse as storage media and receipts as proof of storage. Warehouse Receipt System is listed on:

1. Law of the Republic of Indonesia Number 9 of 2011 concerning Amendments to Law Number 9 of 2006 concerning Warehouse Receipt System;

2. Government Regulation Number 36 of 2007 concerning Implementation of Law Number 9 of 2006 concerning Warehouse Receipt System;

3. Government Regulation Number 70 of 2013 Amendment to Government Regulation Number 36 of 2007 concerning Implementation of Law Number 9 of 2006 concerning Warehouse Receipt System;

4. Government Regulation Number 1 the Year 2016 Implementing Agency for Guarantee System for Warehouse Receipt;

5. Regulation of the Minister of Trade of the Republic of Indonesia Number 33 of 2018 concerning the Third Amendment to the Regulation of the Minister of

${ }^{10}$ Olivia, “Tanggung Jawab Pengelola Gudang Mengenai Resi Gudang Terhadap Kelalaian yang Mengakibatkan Kerugian" 165. 
Trade Number 37 / M-Dag / Per / 11/2011 concerning Goods that can be stored in a warehouse in the implementation of a warehouse receipt system;

6. Several Regulations of the Commodity Futures Trading Supervisory Agency of the Republic of Indonesia.

Currently, the Warehouse Receipt System is useful in the agricultural sector to increase the selling price. For example, as in the current warehousing sector, the Warehouse Receipt System supports employment growth in cooperation with services related to goods in warehouses on warehouse receipts, agriculture, plantation and fisheries, warehousing. In essence, it is also very beneficial for business actors who are in the commodity ecosystem. Examples are the necessity of having a warehouse manager, commodity processing tools such as processing grain into rice, packaging commodities stored for sale, procurement of vehicles, banking, insurance, and Some of the benefits of the warehouse receipt system include: ${ }^{11}$

a. This warehouse receipt system can strengthen the bargaining power of farmers and create efficiency in the world of agribusiness, where farmers can delay the sale of commodities after harvest while waiting for prices to improve again, by storing their crops in specific warehouses that meet the requirements;

b. Farmers can use this warehouse receipt to finance the land planting process and also for manufacturers to fund supplies of raw materials;

c. Mobilizing credit to the agricultural sector. The certainty of guarantees from certain warehouse parties that certain institutions have approved gives confidence for the bank to provide a loan for the warehouse receipt collateral to farmers or traders who store their goods in the warehouse;

d. Minimizing price fluctuations, where farmers do not need to sell their goods immediately after harvest, is usually very low (forced sale). By holding the goods for a while, it is expected that the price will get better;

e. Reducing risks in agricultural product markets, improving food security systems, and opening up access to credit for rural areas;

f. Encourage improving quality and transparency for the warehousing industry because it must comply with specific regulations and carry out supervision.

The core regulations are contained in Law No. 9 of 2006 concerning the Warehouse Receipt System, as amended by Law No. 9 of 2011 concerning the Warehouse Receipt System (from now on referred to as the Warehouse Receipt System Law). Warehouse Receipt's definition is based on Article 1 point (2) of the Warehouse Receipt System Law, a document of proof of ownership of goods stored in the warehouse. According to Article 1 point (4) of the Warehouse Receipt System Law, Warehouses are all immovable rooms for not being visited by the public, but for particular use as storage area, goods that can be traded must meet requirements determined by the Minister.

${ }^{11}$ Zaroni, Sistem Resi Gudang (Bandung: Artikel Supply Chain Indonesia, 2017) 3. 
Meanwhile, according to Article 1 point (5) of the Warehouse Receipt System Law, what is meant by goods is any movable object that can be stored for a certain period and traded in general. Following Article 1, number (8) of the Warehouse Receipt System Law, the Warehouse Manager has the right to issue Warehouse Receipts. Warehouse Manager is a party that carries out a warehousing business, both owned and owned by others, which carries out storage, maintenance, and control of goods stored by the owner of the goods. ${ }^{12}$ Some examples of warehouse managers in Indonesia include PT. Bhanda Ghara Reksa (Persero), PT. Petani (Persero), PT. Pos Indonesia, Kospermindo Makassar, Pasar Maju Bersama Cooperative, and others. ${ }^{13}$

As proof of ownership, warehouse receipts are issued, securities representing goodsstored in the warehouse. ${ }^{14}$ Warehouse receipts is a document of proof of ownership of goods stored in a specially registered warehouse issued by the warehouse manager. ${ }^{15}$ In this context, "warehouse" has various meanings. ${ }^{16}$ The warehouse referred to in this Warehouse Receipt is a warehouse that is only used to store certain commodity items which have been specifically regulated in the Regulation of the Minister of Trade of the Republic of Indonesia Number 33 of 2018 concerning the Third Amendment to the Regulation of the Minister of Trade Number 37 / M-Dag / Per / 11 / 2011 Regarding Items That Can Be Stored in a Warehouse in Implementing a Warehouse Receipt System (from now on referred to as Permendag No.33 of 2018)

Certain goods are categorized as goods that can be stored in a warehouse based on Article 4 of the Minister of Trade Regulation No. 33 of 2018 are: Grain; Rice; Corn; Coffee; Cocoa; Pepper; Rubber; Seaweed; Rattan; Salt; Gambir; Tea; Copra; Lead; Red onion; Fish; and Nutmeg. Requirements for goods stored in a warehouse for issuing warehouse receipts include: ${ }^{17}$

a. Has a shelf life of at least 3 (three) months;

b. Meet specific quality standards;

c. The minimum number of items that can be stored.

Goods in the Warehouse Receipt System include movable goods stored for a certain period and are generally agricultural/plantation/fishery harvested goods. This type of goods has unique characteristics, including: ${ }^{18}$

a. The storage period is relatively shorter than non-agricultural goods;

b. It is perishable or perishable;

c. Is overflow;

${ }^{12}$ Hariyani and Serfianto, Resi Gudang Sebagai Jaminan KreditEAlat Perdagangan 6.

${ }^{13}$ Zaroni, Sistem Resi Gudang 2.

${ }^{14}$ Hariyani and Serfianto, Resi Gudang Sebagai Jaminan KreditE Alat Perdagangan 12.

${ }^{15}$ Zaroni, Sistem Resi Gudang 2.

${ }^{16}$ NFN Ashari, “Potensi dan Kendala Sistem Resi Gudang (SRG) untuk Mendukung Pembiayaan Usaha Pertanian di Indonesia" Forum Penelitian Agro Ekonomi. 29.2 (2016): 131.

17 Trisadini Prasastinah Usanti and Leonora Bakarbessy, Referensi Hukum Perbankan: Hukum Jaminan, (Surabaya: Revka Petra Media, 2016) 152.

${ }^{18}$ Hariyani and Serfianto, Resi Gudang Sebagai Jaminan KreditEAlat Perdagangan 15. 
d. The storage process in the warehouse must be controlled more tightly because it is susceptible to pests;

e. The quality of goods is strongly influenced by the post-harvest processing process, especially the drying process and the grading-sorting process, and

f. Prices of agricultural harvested goods tend to fluctuate and are strongly influenced by seasons.

According to Article 1 point (7) of the Warehouse Receipt System Law, the good owner is said to be a Warehouse Receipt Holder, namely the party who receives the goods owner's transfer.

The Warehouse Receipt Law also regulates the various types and forms of Warehouse Receipt. There are 2 (two) types of Warehouse Receipt, namely: ${ }^{19}$

1. Warehouse Receipt on Name is a Warehouse Receipt that states the name of the party entitled to receive delivery of goods;

2. On Order, Warehouse Receipt is a Warehouse Receipt that states the party's order is entitled to receive goods.

While the form consists of:

1. Warehouse Receipt with Clearing Items are securities whose ownership is in the form of a certificate either on behalf of or order;

2. Scriptless Warehouse Receipts are securities whose ownership is recorded electronically.

Warehouse receipt implementation begins with parties such as farmers or business actors who wish to reserve their commodity goods to visit the designated warehouse. Then the commodity goods to be inspected are tested by a particular institution, namely the Conformity Assessment Agency, which is in charge of trying the quality of the commodity and making certificates for goods containing information about the commodity goods such as how the number of goods, class of goods, a period of quality of goods, to the signature of the authorized party. ${ }^{20}$ With this test's existence, it is intended that whether the commodity goods to be warehoused have met the predetermined requirements. Then the Warehouse Manager will create a Goods Management Agreement, which contains a description of the goods and insurance. After receiving the registration code, the Warehouse Manager will issue a Warehouse Receipt which includes information about the title of the Warehouse Receipt of the goods of the parties being reserved, the name of the owner of the item, which warehouse location will be used to store the commodities of the parties, date and issue number, number registration, maturity date, description of goods, cost of storage, the value of goods to market prices. Then the Warehouse Manager submits all information and data that has been received to the Supervisory Agency. After all, procedures have been

${ }^{19}$ Usanti and Bakarbessy, Referensi Hukum Perbankan: Hukum Jaminan 150.

${ }^{20}$ Ninis Nugraheni, "The Movable Goods As A Collateral Object In Warehouse Receipt System" Hang Tuah Law Journal. 2.1 (2018): 97. 
carried out; Warehouse Receipt can be issued and immediately used by the parties concerned, whether cashed, stored as an asset, or even traded or traded. ${ }^{21}$

Based on the explanation above, it can be understood that warehouse receipts are part of the warehouse receipt system, a "receipt" representing whatever is stored in the warehouse. Because the warehouse cannot be used to store goods that are not stated in the Minister of Home Affairs Regulation, the goods stored in the warehouse have high economic value, especially for some social elements. The existence of a Warehouse Receipt System in the business world is currently being used as an alternative in dealing with financing problems in the business sector. Regarding the field of financing, the warehouse receipt as a form of evidence of goods in the warehouse, it is necessary to conduct further study, whether it is also an object that has economic value, or is it just a description of a list of items that have a monetary value

Based on the detailed classification of object types in Book II BW, objects can be objects of transactions. Like the Warehouse Receipt in the Warehouse Receipt System. A warehouse Receipt is an object that is tangible and movable and gives birth to material rights, namely material rights that provide enjoyment. Warehouse Receipt as an object, then it should be used as the object of the transaction; however, this must be reviewed first, considering that the item of the trade is at least following Article 1131 $\mathrm{BW}$, which has economic value and is transferable, it is necessary to examine whether Warehouse Receipt has 2 (two) characteristics, considering that warehouse receipts are only a description of goods stored in the warehouse.

Based on the description above, it can be examined that a Warehouse Receipt, which is a certificate of goods stored in the warehouse, also has the character of representing the said objects based on the detailed information provided. This is as stated in Article 4 of Government Regulation Number 36 of 2007 concerning Implementation of Law Number 9 of 2006 concerning the Warehouse Receipt System, which confirms that Warehouse Receipt Documents are valid if they contain:

1. Title of Warehouse Receipt;

2. Types of Warehouse Receipt;

3. Name and address of the owner of the goods;

4. Location of the warehouse where goods are stored;

5. The date of issue;

6. Issuance number;

7. Time due;

8. Description of goods;

9. Storage costs;

${ }^{21}$ Bappepti, Panduan Pelaksanaan Sistem Resi Gudang (Jakarta: Kementerian Perdagangan Republik Indonesia, 2017) 18. 
10. Value of goods based on the market price at the time the goods are entered into the warehouse;

11. Security code;

12. Warehouse Manager letterhead; and

13. Signature of the owner of the goods and signature of the Warehouse Manager. This means that the warehouse receipt has economic value. Therefore, the Warehouse Receipt can also be transferred, although it does not automatically transfer ownership only by actual delivery like the conditions for transferring movable objects. Still, for a perfect transfer of ownership rights, the Warehouse Receipt's name must be reversed.

Indonesia has several rules governing guarantee institutions both in BW and inlaws outside BW. The rules that exist in BW and which are specifically issued by the government regarding material guarantees are:

a. The Pledge regulated in Article 1150-1160 BW;

b. The mortgage is regulated in Articles 1162-1232 BW;

c. Law No. 4 of 1996 concerning Hak Tanggungan (from now on referred to as UUHT);

d. Law No. 42 of 1999 concerning Fiduciary Guarantee (from now on referred to as UUJF).

The material guarantee institution as above, considering that the rules are in positive law in Indonesia, then gives birth to the right to material security. The characteristics of the material guarantee rights contained in each guarantee institution in Indonesia include: ${ }^{22}$

1. The Absolute Principle;

2. Droit De Suite Principles;

3. The Droit De Preference Principle;

4. The Droit De Priority Principle;

5. Material Claims;

6. Principle of totality;

7. The Principle of Specialization;

8. Principles of Publicity.

Because Warehouse Receipt is an object, therefore the form of guarantee is the material guarantee. There are no laws and regulations that mandate the imposition of warehouse receipts as collateral objects. One of the rules regarding Warehouse Receipt which contains the guarantee of Warehouse Receipt itself, is Government Regulation No. 36 of 2007, namely concerning the Implementation of Law no. 9 of 2006 as amended by Law no. 9 of 2011 concerning Warehouse Receipt System (from now on referred to as PP Warehouse Receipt). In the PP, it is stated about the imposition of

${ }^{22}$ Fani Martiawan Kumara Putra, "Karakteristik Pembebanan Jaminan Fidusia Pada Benda Persediaan Dan Penyelesaian Sengketa Saat Debitor Wanprestasi” Perspektif. 21.1 (2016): 39. 
guarantee rights on Warehouse Receipts contained in Chapter IV Article 16 paragraph 1 that Warehouse Receipts can be burdened with Security Rights for debt repayment. However, it is necessary to examine whether the PP. 36 of 2007, there are principles in the guarantee law, namely the nature of the property security right.

In the PP Warehouse Receipt, several principles of material security rights are found, including the principle of Droit de preference (Article 16 paragraph 2; regarding the position of the recipient of the guaranteed right as the preferred creditor), the principle of publicity (Article 18 paragraph 1; regarding the recording of the imposition of receipt guarantee rights. warehouse), the principle of specialty (Article 23 paragraph 2; regarding notification of the sale of the warehouse receipt object, precise data must be included), and the principle of execution (Article 21; which states that the creditor has the right to sell the item of the Warehouse Receipt guarantee right on his power without assistance court (parate execution)).

Warehouse Receipt Guarantee in PP Warehouse Receipt process is described in the Attachment to the Regulation of the Head of Commodity Futures Trading Supervisory Agency (BAPPEBTI) No. 09/BAPPEBTI/PER-SRG/7/2008 Attachment of the Head of Bappebti No. 9 of 2008 contains about how the procedure mechanism or procedures for imposition of guarantee rights and notification of guarantee rights, the removal of the object of guarantee, and the sale of the item of guarantee. The procedure or mechanism for assigning Guarantee Rights on Warehouse Receipts is explained as follows:

a. After the agreement is made between the owner of the Warehouse Receipt and the prospective recipient of Guarantee Rights, the prospective recipient of the Guarantee Rights submits a verification application for Warehouse Receipt which will be subject to Security Rights through the Online Warehouse Receipt System to the Registration Center;

b. The Registration Center verifies the application containing the validity of the Warehouse Receipt, the validity of the Giver of Guarantee Rights, the period of the Warehouse Receipt, the value of the Warehouse Receipt at the time of issuance, and a statement regarding whether or not the Security Right has been charged;

c. The Registration Center will provide the Registration Center for confirmation of whether or not it can be imposed by submitting Confirmation Evidence through the Online Warehouse Receipt System;

d. The Giver of Guarantee Rights and Guarantee Rights Recipients sign the Collateral Right Imposition Agreement on Warehouse Receipt, a follow-up agreement from the main deal, namely the credit agreement. The signing of the Collateral Right Imposition Agreement on Warehouse Receipt can be done under the hand or in front of a notary. Where in the agreement, additions, and 
adjustments can be made based on needs as long as it does not conflict with the provisions of the Warehouse Receipt Law and its implementing regulations;23

e. The Collateral Right Recipient notifies the Imposition of Guarantee Rights through the Online Warehouse Receipt System to the Registration Center and Warehouse Management and submits the notification by attaching data in the form of Confirmation Proof of Warehouse Receipt Can Be Burdened With Security Rights from the Registration Center, a photocopy of the Collateral Right Imposition Agreement on Receipt Warehouse and a photocopy of Warehouse Receipt, no later than the next day after the signing of the Collateral Right Assurance Agreement on Warehouse Receipt. Risks that arise due to negligence or deliberately of the Guarantee Rights Recipient in the event of a delay or not notifying the Imposition of Guarantee Rights are entirely the responsibility of the Guarantee Rights Recipient;

f. The Registration Center updates the status of Warehouse Receipt and records Collateral Rights Assignment into the Collateral Rights Assignment List;

g. Registration Center sends proof of confirmation that it has been received and that notification of the imposition of Guarantee Rights through SRG-Online has been recorded to the recipient of Guarantee Rights, Guarantee Rights giver, and Warehouse Manager, no later than the following day after the notification of the imposition of Guarantee Rights has been received ultimately.

The Attachment of the Head of Bappebti No. 9 of 2008 also found several principles of material security rights, namely the principle of publicity regarding the mechanism for charging warehouse receipt guarantees that must be registered. The specialty regarding data relating to the warehouse receipt collateral object must be clear to facilitate the execution process. In essence, the principle of property security rights in the Attachment of the Head of Commodity Futures Trading Supervisory Agency No. 9 of 2008 does not deviate from the PP Warehouse Receipt Guarantee, which is, is a follow-up to the PP Warehouse Receipt Guarantee.

However, one principle of material security rights that is not contained in the two regulations, namely the Droit de suite principle, is not found. There is no explanation that the warehouse receipt guarantee rights will always follow wherever the object is. As it is known, for material rights and material security rights, these three principles are interrelated, namely absolute, droit de suite, and material claim. There will be no material suitability (for example, in the execution framework) if there is no droit de suite characteristic. Nor can the absolute principle apply where there is no droit de suite property. When the receipt is transferred in bad faith, the creditor will not be able to ask for it back because the property security rights attached to it are eventually lost.

${ }^{23}$ Fani Martiawan Kumara Putra, "Characteristics of Notary Deeds for Transactions Through Electronic Media" NORMA. 17.3 (2021): 3. 
It should also be borne in mind that the above rules, which mention warehouse receipt guarantee agencies, are in regulations that are not at the level of law. It is appropriate that the rules regarding the guarantee institution are put in the law; this is as the guarantee institution for Pledge, Fiduciary, Mortgage, Hak Tanggungan, comprehensive rules are all contained in the law. It is proper to use a hierarchical regulation under the law but limited to the implementation. This is different from the Warehouse Receipt as described above; the Warehouse Receipt Law does not emphasize the existence of a Warehouse Receipt guarantee agency; it only states that warehouse receipts can be used as collateral objects, meaning that in the Warehouse Receipt Law there is no new guarantee institution born, no warehouse receipt guarantee institution is born.

The description above, of course, is an explanation from a theoretical and academic perspective, considering that a principle or principle must be realized in the form of a norm, including Droit de Suite in guaranteeing warehouse receipts cannot be regarded as existing, considering that it is not normalized. However, practitioners perceive it; differently, practitioners, be they legal practitioners, actors, or observers of the people's economy (especially farmers), including banks (especially those in villages), acknowledge the existence of warehouse receipt guarantee institutions. This is reasonable, considering that even though it is not according to the norms, this warehouse receipt guarantee institution is instrumental in farmers' environment (villages) to revive the economy and continue its business. When there is a dispute of opinion, we must move on to existing theories and norms. Therefore, in the Warehouse Receipt Law, no new guarantee institution was born, no warehouse receipt guarantee institution was born, and even though it is considered to exist, it still cannot implement the nature of the guaranteed right. The material in the form of Droit de suite means that the debtor's protection will be weak.

As described above, in its use, warehouse receipts can indeed be the object of transactions by being traded; one of the conditions is a change of name. Based on the description above, warehouse receipts should not be used as collateral. Given its character as an object of economic value and transferable property rights, warehouse receipts can be used as legal objects for the engagement, especially in the event of debt and credit, by utilizing the Fiduciary Guarantee Agency, considering that this guarantee institution is specifically for movable objects, and there is no inbezitstelling principle. As in Pledge, it is, therefore, suitable for Warehouse Receipt. However, in the Fiduciary Guarantee, a Fiduciary Security Deed is required by a Notary, considering that the debtor's subject is generally rural farmers, so it will be quite burdensome when you have to pay for notary services, and also the distance to the Notary's office which is relatively far from rural areas. 


\section{CLOSING}

\section{Conclusion}

Warehouse receipts are the main items in the warehouse receipt system. As the name implies, as a receipt, which contains a description of the goods stored in the warehouse, the types of goods and the storage mechanism are regulated in separate regulations. Warehouse receipt as an object can be classified as a moving object. Given the substance and character of the warehouse receipt itself, it can be understood that warehouse receipts are objects that have economic value. As objects that have monetary value, it means that warehouse receipts have the potential to be transferred. The character of warehouse receipts, which are economically valuable and their property rights, can be transferred, making warehouse receipts the object of a legal relationship, one of which is the civil law relationship in the form of debts. The practitioners acknowledge the existence of a warehouse receipt guarantee agency. However, there is no affirmation that when the warehouse receipt is guaranteed in this arrangement, there will be droit de suite characteristics; therefore, there is also no material suitability and absolute nature. Thus, the guarantee parties cannot get comprehensive protection. Apart from that, it needs to be understood that the guarantee institution was born from the law. At the same time, the Warehouse Receipt Law does not emphasize the existence of a Warehouse Receipt guarantee agency; it only states that warehouse receipts can be used as objects of guarantee.

\section{Recommendation}

Warehouse Receipt arrangements need to be continuously considered and developed, considering that this institution can significantly assist the farmer's economy, particularly by developing warehouse specifications to store more types of objects. The government needs to make rules to guarantee institutions with warehouse receipts as its objects.

\section{REFERENCES}

Ashari, NFN. "Potensi dan Kendala Sistem Resi Gudang (SRG) untuk Mendukung Pembiayaan Usaha Pertanian di Indonesia." Forum Penelitian Agro Ekonomi 29.2 (2016): 129.

Bappepti. Panduan Pelaksanaan Sistem Resi Gudang. Jakarta: Kementerian Perdagangan Republik Indonesia, 2017.

Hariyani, Iswi, and R Serfianto. Resi Gudang Sebagai Jaminan KreditEAlat Perdagangan. Jakarta: Sinar Grafika, 2010.

Putra, Fani Martiawan Kumara. "Characteristics of Notary Deeds for Transactions Through Electronic Media." NORMA 17.3 (2021): 1-14

Nugraheni, Ninis. "The Movable Goods As A Collateral Object In Warehouse Receipt System." Hang Tuah Law Journal 2.1 (2018): 95-103. 
Olivia, Fitria. “Tanggung Jawab Pengelola Gudang Mengenai Resi Gudang Terhadap Kelalaian yang Mengakibatkan Kerugian." Jurnal Lex Jurnalica 10.3 (2013): 161173.

Pusat Kebijakan Perdagangan Dalam Negeri. Analisis Efektifitas Sistem Resi Gudang Melalui Pasar Lelang Forward Komoditi. Jakarta: Kementerian Perdagangan Republik Indonesia, 2015.

Putra, Fani Martiawan Kumara. “Karakteristik Pembebanan Jaminan Fidusia Pada Benda Persediaan Dan Penyelesaian Sengketa Saat Debitor Wanprestasi." Perspektif 21.1 (2016): 34-47.

- - - "Konstruksi Lembaga Jaminan Untuk Saham Sebagai Bentuk Dukungan Perkembangan Bisnis." Perspektif 23.2 (2018): 66-75.

Setiono, Gentur Cahyo. “Jaminan Kebendaan dalam Proses Perjanjian Kredit Perbankan (Tinjauan Yuridis Terhadap Jaminan Benda Bergerak Tidak Berwujud)." Transparansi Hukum 1.1 (2018): 1-18. Available: http://ojs.unik-kediri.ac.id/index. php/transparansihukum/article/view/159.

Supramono, Gatot. Perjanjian Utang Piutang. Jakarta: Kencana Media, 2013.

Suwandi, Suwandi. “Kedudukan Jaminan Antara Utang-Piutang Dan Rahn." Jurisdictie: Jurnal Hukum dan Syariah 7.2 (2016): 203-218.

Usanti, Trisadini Prasastinah, and Leonora Bakarbessy. Referensi Hukum Perbankan: Hukum Jaminan. Surabaya: Revka Petra Media, 2016.

Yuswalina. “Hutang-Piutang dalam Prespektif Fiqh Muamalah di Desa Ujung Tanjung Kecamatan Banyuasin III Kabupaten Banyuasin." Intizar 19.2 (2016): 395-410.

Zaroni. Sistem Resi Gudang. Bandung: Artikel Supply Chain Indonesia, 2017. 